AGRICULTURE AND BIOLOGY JOURNAL OF NORTH AMERICA

ISSN Print: 2151-7517, ISSN Online: 2151-7525, doi:10.5251/abjna.2011.2.5.752.760

(C) 2011, ScienceHuß, http://www.scihub.org/ABJNA

\title{
Evaluation of ecologies and severity of Striga weed on rice in sub-Saharan Africa
}

\author{
Evans A. Atera ${ }^{1,2^{*}}$, Kazuyuki Itoh ${ }^{1}$ and John C. Onyango ${ }^{3}$ \\ ${ }^{1}$ Graduate School of Agricultural Science, Kobe University, 1-1 Rokkodai-cho, Nada-ku, \\ Kobe, 657-8501, Japan; ${ }^{2}$ Department of Technical Services, Lake Basin Development \\ Authority, Kenya; ${ }^{3}$ Department of Botany and Horticulture, Maseno University, Kenya; \\ *Corresponding Author: eatera@yahoo.com
}

\begin{abstract}
Striga spp. is renowned for causing great losses in cereal production in sub-Saharan Africa. Crop competitiveness with parasitic weeds such as Striga is an important criterion for selection in an initiative to produce and release rice cultivars to farmers that are able to give high and stable yields under low-input conditions. The symptoms of Striga infected rice plants are chlorosis, wilting and stunted growth. Rice yield is reported to be reduced by more than $50 \%$ in areas that are infested by the weed. In addition, areas that are heavily infested have been abandoned and rendered unfit for crop production. Notable advances in Striga weed control technology have been made, yet the weed continues to be a major cause of low agricultural production. This is an indication of poor linkage between research institutions and agricultural extension which is a bottleneck to research findings to benefit farmers.
\end{abstract}

Keywords: Striga spp., host plants, rice, Striga occurrence, tolerance

\section{INTRODUCTION}

Parasitic weeds are problematic in Agricultural Production Systems (APS) in the world today. The weeds compete with crops for nutrients, water and harbor disease causing organisms. Root parasitic weeds such as orobanche (broomrape) and Striga (witchweed) compensates for lack of their own root system by penetrating the roots of host plants and thus depriving the essential nutrients for plant growth. This brings about stagnation of the host plants with the end result of low yield (Watson et al., 1998). Striga species predominantly found in Africa infest land planted with sorghum (Sorghum bicolor [L.]), pearl millet (Pennisetum glaucum [L.]), finger millet (Eleusine coracana [L.] Gaertn), maize (Zea mays [L.]), upland rice (both Oryza glaberrima [Steudel] and $O$. sativa [L.]) and cowpea (Vigna unguiculata [L.] Walp) (Musselman, 1980; Rodenburg et al. 2006; Scholes and Press 2008).

Striga, the parasitic angiosperm weed is said to be the major problem in cereal production causing huge losses in grain yield. The diversity of Striga spp. populations in African countries need to be understood to identify the races found in the different agro-ecological zones. This will enable improvement of the existing crop material through breeding that can withstand the stress of the weed. Striga hermonthica has particularly assumed economic importance in upland rice growing areas in West and East African countries.

The epicenter of Striga is believed to be in the tropical savannah between Semien Mountains of Ethiopia and Nubian hills of Sudan in SSA before spreading to other parts of the continent (Ejeta, 2007). This area is also recognized as the origin of sorghum and pearl millet which are readily infected by Striga. Over 70 years, several world institutions both private and public have dedicated substantial amount of money towards developing appropriate mechanisms to control the parasite (Ahmed et al., 2001). Despite the efforts made to control the Striga problem, farmers have not adopted the control options developed (Oswald, 2005). This is one of the greatest tests to be synthesized by the researchers and unearth the reasons behind the farmers not embracing the preventive measures (Emechebe et al., 2004).

Striga seed production paradox need to be underscored as the parasite produces many tiny seeds which are capable of existing in the soil for more than 10 years (Hearne, 2009). This has enhanced the parasites' persistence and increase in magnitude. Therefore, this review focuses on the distribution and effect of Striga spp. on cereal 
production particularly rice. The paper first reviews the importance of rice and the extent of infestation of Striga spp. in SSA. Assessment on the occurrence of the parasites in their current habitats is highlighted. Finally, rice cultivars tolerance levels to Striga is discussed.

Significance of rice production : Rice is a major staple food for approximately half of the world's population. It is one of the major food crops in SSA with an estimated cultivated area of about 6.8 million hectares. The total rice production in the region is about 21.6 million tons in 2006 (FAO, 2007). The demand of rice has been increasing at rate of $4.4 \%$ per annum since 1970s which is as result of dietary shift from conventional foods, brought about by urbanization and increase in population (Jones, 1999). Production has also been growing at rate of $5.1 \%$ per year with approximately $70 \%$ due to increased area under cultivation and $30 \%$ on yield. Upland rice has been leading on expansion in the area under production particularly with the incoming of New Rice for Africa (NERICA) (Otsuka and Kalirajan, 2006).

Rice is slowly becoming one of the most important crops in the continent both for food and cash. Obilana and Okumu (2005) reported that upland rice has brought remarkable impact in farmers' livelihoods on poverty reduction, improved nutrition and increased cash income generation. In addition, reduction of the growing period of NERICA rice has bridged the gap of hunger and brought about saleable products. This implies that there is availability of ready cash for household use. Research has also shown that a hectare of rice can sustain 5.7 persons per year as compared to 5.3 and 4.1 for maize and wheat respectively. The world food total calorie out-put is approximately $3119 \mathrm{k}$ cal. /person per day at farm gate, with rice accounting for $552 \mathrm{k}$ cal. /person per day or $18 \%$ of the total (De Datta, 1981). However, one of the major constraining factors in production of upland rice in sub-Saharan Africa is weed infestation especially Striga spp. The problem of weeds in upland rice is exacerbated by delayed and poor land preparation as well as inefficient weeding associated with broadcast sowing, random transplanting and lack of appropriate agricultural implements.

\section{DISTRIBUTION AND INFESTATION OF STRIGA IN SSA}

Striga weed infestation and occurrence: There are 28 Striga species occurring naturally, infecting grasses and legumes in SSA. Most of the crop host species for Striga are cereals which Africans depend on as food (Table 1). The parasite infests some $40 \%$ of the cereal-producing areas of SSA resulting to crop losses estimated at US\$7 billion annually, affecting livelihoods of approximately 300 million people (Ejeta, 2007). The most affected are subsistence farmers losing about $20-80 \%$ of their yield (Gethi et al., 2005).

It has been reported that five of the Striga spp. cause devastating effects on crops: S. hermontica, S. asiatica, S. forbsii, S. aspera and S. gesnerioides (Berner et al., 1997). Table 2 shows the distribution of Striga in Africa and S. asiatica is said to have a wide world geographic distribution as compared to others (Cochrane and Press, 1997). Dugje et al. (2006) stated that in Nigeria three major Striga species have been found to be infecting crops: $S$. hermonthica (sorghum, rice and maize), S. aspera (rice) and S. gesnerioides (cowpea). In the savannas of guinea, S. aspera occurs in the hydromorphic areas where rice is grown, while $S$. hermonthica and $S$. asiatica are found in the free draining upland areas and are regarded as the most infectious (Johnson et al., 1997). Notably S. aspera is predominantly found in West Africa and sporadically exists in Ethiopia and Tanzania overlapping with S. hermonthica. 
Agric. Biol. J. N. Am., 2011, 2(5): 752-760

Table 1. Degree of Striga infestation on crops in SSA

\begin{tabular}{lccccccc}
\hline & \multicolumn{7}{c}{ Crops } \\
\cline { 2 - 7 } Striga species & Maize & Sorghum & Rice & $\begin{array}{c}\text { Pearl } \\
\text { millet }\end{array}$ & $\begin{array}{c}\text { Finger } \\
\text { millet }\end{array}$ & Cowpea & Sugarcane \\
\hline S. hermonthica & $\mathrm{xxx}$ & $\mathrm{xxx}$ & $\mathrm{xx}$ & $\mathrm{xx}$ & $\mathrm{xxx}$ & - & $\mathrm{xx}$ \\
S. angustifolia & - & $\mathrm{xx}$ & - & - & - & - & $\mathrm{xx}$ \\
S. asiatica & $\mathrm{xxx}$ & $\mathrm{xxx}$ & $\mathrm{xx}$ & $\mathrm{xx}$ & $\mathrm{xx}$ & - & $\mathrm{x}$ \\
S. forbesii & $\mathrm{x}$ & $\mathrm{x}$ & $\mathrm{x}$ & - & - & - & $\mathrm{x}$ \\
S. aspera & $\mathrm{xx}$ & $\mathrm{x}$ & $\mathrm{xx}$ & - & $\mathrm{x}$ & - & $\mathrm{x}$ \\
S. gesnerioides & - & - & - & - & - & $\mathrm{xxx}$ & - \\
S. latericea & - & - & - & - & - & - & $\mathrm{x}$ \\
S. pubiflora & - & - & - & - & - & - & $\mathrm{x}$ \\
\hline
\end{tabular}

xxx- Serious infection, xx-Moderate infection, $x$-Less infection, --No infection

Source: Parker and Riches, 1993

Generally Striga spp. grows in areas with annual rainfall ranging from $25-150 \mathrm{~cm}$ per year with decrease in severity of infestation in areas of high rainfall (Mohamed et al., 1998). However, S. forbisii mainly occurs in wet areas and even in water logged conditions infecting wild grasses in swamps and irrigated crops (Mohamed et al., 2001) in Cote d'Ivore and Tanzania. There are records indicating $S$. hermonthica and $S$. aspera infections on rice in Northern Cameroon, Northern Nigeria, Benin, Togo and westwards. It has also been reported that $S$. hermonthica infects upland rice in Western Kenya (Harahap et al., 1993) and S. asiatica causes serious losses in upland rice along the Indian Ocean Islands.

\section{Conditions favoring Striga growth: Striga} infestation is steadily increasing as a result of continuous cultivation of cereal crops. Overused, depleted and infertile soils have resulted to high infestation of Striga. Pressure on land for continuous cropping of high yielding cereal crops without rotation or moving to other new areas has resulted to exhausted soils. These are the soils that favor Striga infestation in addition to soil moisture stress conditions (Khan et al., 2007). Less shading due to poor growth of the host crop on poor soils contributes to heavy infestation. This has compounded the problem for small-scale farmers who can least afford inputs on unproductive land, and thus continues mono-cropping (planting of the same crop on the same area) for several years. Infestation in some areas has reduced yield to the extent that abandonment and migration is necessary. Improper management of Striga weed has contributed to its existence in SSA for a long time.

Poverty level of small scale farmers has enhanced the spread of Striga through sharing of seeds collected from the previous crop harvest. In addition, Striga pandemic in SSA has increased due to non advocacy of nutrient replenishment of the soils as a result of mono-cropping, a factor for increased infestation of the weed in size and severity (Woomer, 2004).

Striga produces several seeds, and during tillage the seeds are incorporated into the soil where they can be dormant for many years. Over time they are 
spread to new areas by human beings through the tools used for land preparation and weeding (Oswald, 2005). The seeds are also spread by animals moving from one field to another for grazing purposes (Hearne, 2009). This has culminated to a complex system of spreading the weed to new areas thus reducing crop yield of farmers who are not aware of the devastating effect.

Soil fertility and Striga weed: Parasitic weeds such as Striga establish preferentially in poor nutrient fields which have been exhausted by continuous cropping (Kim, 1997). Most Striga infested areas are characterized by APS exhibiting low productivity. These areas tend to be managed traditionally with low inputs and continuous cereal cropping without crop rotation. The use of inorganic nitrogen and organic fertilizers such as manure and compost has been reported to reduce Striga infestations (Kuiper, 1998). Manure applications have been shown to be as effective as fallowing in maintaining soil productivity. The positive benefits of applying manure include an increase in $\mathrm{pH}$, water holding capacity, hydraulic conductivity, infiltration rate and decrease in bulk density. Manure is also an important source of $\mathrm{N}, \mathrm{P}$ and $\mathrm{K}$ (Kim, 1997). To enhance the quality and effectiveness of traditional soil fertility maintenance strategies such as manure application, a fertilizer augmented soil enhancement strategy need to be adopted to reduce the infections of Striga.

Field trials conducted in the dry and wet seasons in the northern Guinea Savanna ecological zone to study the effect of nitrogen rates on upland rice (Oryza sativa L.) varieties to Striga hermonthica indicated that FARO 48, a variety normally susceptible to Striga hermonthica exhibited resistance, FARO 11 exhibited tolerance, while FARO 38, FARO 46 and FARO 45 exhibited susceptibility. The application of 90 and $120 \mathrm{~kg} \mathrm{~N} \mathrm{ha}^{-1}$ delayed and reduced Striga emergence on the crop, induced a low crop reaction score and produced grain yields that were significantly high. Significant differences in Striga infestation were observed between nitrogen rates of $30-120 \mathrm{~kg} \mathrm{~N} \mathrm{ha}^{-1}$ (Adagba et al., 2002).

The significant interaction between upland rice varieties and nitrogen rates indicates that the susceptible varieties require higher rates of nitrogen to ameliorate the effect of Striga compared with the resistant varieties. In addition, Johnson et al. (1997) showed that the proportion of 0 . glaberrima and 0 . sativa plants that appear stunted, is related to the number of Striga plants present. The increasing incidences and severity of Striga damage is linked to poor soil fertility which is due to lack of farm yard manure and inorganic fertilizers (Emechebe et al., 2004).

Incidence and severity of striga on rice: Johnson (1996) reported that $20-100 \%$ of yield loss in rice fields depend on the farmers' control of weeds. Striga is a common parasitic weed which alone reduces yields of cereal crops such rice more than 50\% (Johnson et al., 1997). As shown in Table 1 there are four known Striga spp. that infect rice:- $S$. hermonthica, S. asiatica, S. aspera and S. forbesii. In the rural communities of Northern Nigeria, it has been reported that crop yield losses due to $S$. hermonthica infections were about 70-100\% (Emechebe et al., 2004). It has also been reported that crops can show resistance characteristic in one area and succumb in another because resistance can be broken by the existing biotypes (Gethi et al. 2005). This was observed in Tanzania where sorghum was planted in different locations (Doggett 1952) and similar observations have been made in West Africa (Ramahiah 1987).

Susceptible and resistant rice cultivars: Johnson et al. (1997) describes two $O$. sativa cultivars, IR47255-B-B-5-4 and IR49255-B-B-5-2, having resistance to $S$. hermonthica and limited susceptibility to $S$. aspera enabling to support 2-3 emerged parasite stems per rice plant compared to over 20 on the susceptible cultivars which are widely grown in infested areas of Cote d'Ivore (Table 3). However, in general cultivars of African rice species, $O$. glaberrima more often show Striga resistance as compared to O. sativa (Johnson et al., 1997). Johnson et al. (2000) reported that O. glaberrima cultivar CG14 is resistance to $S$. hermonthica and S. aspera which is one of the parents of NERICA rice, currently being promoted for food security in SSA for their short maturity period, drought resistance and high yield. However, it has also been shown by some post-attachment studies to be susceptible to $S$. hermonthica (Gurney et al. 2006). The screening of NERICAs against Striga spp. is necessitated as the most productive areas for upland rice are heavily infested. Furthermore, the contradictory information on CG14 on resistance and susceptibility to Striga infections will be confirmed and reported in this journal.

Incidence and severity of S. hermonthica, S. asiatica, $S$. aspera and $S$. forbesii (in decreasing order of importance) parasitizing rice are particularly high in the savannahs of West Africa with relatively high 
Table 2. Distribution and occurrence of Striga spp. in sub-Saharan Africa

\begin{tabular}{|c|c|c|}
\hline Striga species & Host plants & Distribution \\
\hline S. aequinoctialis & & Guinea, Angola, Liberia, Siera Leone \\
\hline S. angolensis & & Angola \\
\hline S. angustifolia & Sorghum, Sugarcane & Malawi, Tanzania, Zambia, Zimbabwe \\
\hline S. asiatica & Rice, Sorghum, & $\begin{array}{l}\text { Angola, Kenya, Lesotho, Malawi, Mozambique, Sudan, Namibia, Tanzania, Madagascar, } \\
\text { South Africa, Zanzibar, Zambia, Botswana, Burundi, Democratic Republic of Congo }\end{array}$ \\
\hline S. aspera & $\begin{array}{l}\text { Rice, Maize, Sorghum, Finger } \\
\text { Millet, Wild grasses, Sugarcane }\end{array}$ & $\begin{array}{l}\text { Burkina Faso, Cameroon, Central Africa Republic, Ethiopia, Gambia, Guinea, Cote d'ivoire, } \\
\text { Nigeria, Niger, Mali, Ghana, Senegal, Sudan }\end{array}$ \\
\hline S. bilabiata & & $\begin{array}{l}\text { Burundi, Guinea Bissau, Niger, Nigeria, Guinea, Angola, Uganda, Democratic Republic of } \\
\text { Congo, Mali, Zambia, Malawi, Cameroon, Burkina Faso, Ethiopia, Central Republic of Africa, } \\
\text { Cote d'ivoire, Kenya, Tanzania, South Africa }\end{array}$ \\
\hline S. brachycalyx & & Burkina Faso, Democratic Republic of Congo, Ghana, Cote d'ivoire, Nigeria \\
\hline S. chrysantha & & Central African Republic \\
\hline S. dalzielii & & Guinea, Mali, Nigeria \\
\hline S. elegans & & $\begin{array}{l}\text { Angola, Botswana, Kenya, Malawi, Mozambique, Namibia, South Africa, Swaziland, } \\
\text { Tanzania, Zambia, Zimbabwe }\end{array}$ \\
\hline S. forbesii & $\begin{array}{l}\text { Sugarcane, Maize, Sorghum, } \\
\text { Rice }\end{array}$ & $\begin{array}{l}\text { Angola, Botswana, Democratic Republic of Congo, Ethiopia, Kenya, Malawi, Mozambique, } \\
\text { South Africa, Sudan, Swaziland, Tanzania, Uganda, Zambia, Zimbabwe }\end{array}$ \\
\hline S. gastonii & & Chad, Central African Republic \\
\hline S. gesnerioides & Cowpeas, Wild legumes & $\begin{array}{l}\text { Angola, Botswana, Burkina Faso, Burundi, Cameron, Central African Republic, Democratic } \\
\text { Republic of Congo, Ethiopia, Sierra Leone, Senaral, South Africa, Tanzania, Zimbabwe, } \\
\text { Gambia, Ghana, Kenya, Malawi, Mali, Mozambique, Somalia, Nigeria, Ruanda, Uganda, } \\
\text { Zambia }\end{array}$ \\
\hline
\end{tabular}


Agric. Biol. J. N. Am., 2011, 2(5): 752-760

\section{Table 2. Continued}

\begin{tabular}{|c|c|c|}
\hline Striga species & Host plants & Distribution \\
\hline S. gracillima & & Malawi, Tanzania \\
\hline S. hallaei & & Gabon, Democratic Republic of Congo \\
\hline S. hermonthica & $\begin{array}{l}\text { Maize, Rice, Sorghum, Pearl } \\
\text { millet, Finger millet, Sugarcane }\end{array}$ & $\begin{array}{l}\text { Angola, Cameron, Central Africa Republic, Democratic Republic of Congo, Djibouti, Eritrea, } \\
\text { Gambia, Guinea Bissau, Ethiopia, Cote d'ivoire, Niger, Kenya, Senegal, Sudan, Chad, Uganda, } \\
\text { Tanzania, Togo, Namibia, Nigeria }\end{array}$ \\
\hline S. hirsuta & & $\begin{array}{l}\text { Angola, Burkina Faso, Central African Republic, Democratic Republic of Congo, Kenya, } \\
\text { Ethiopia, Mozambique, Somalia, Nigeria, Seychelles,Tanzania, Zambia }\end{array}$ \\
\hline S. junodii & & Mozambique, South Africa \\
\hline S. klingii & & Ethiopia, Kenya, Tanzania \\
\hline S. latericea & Sugarcane & Ethiopia, Kenya, Tanzania \\
\hline S. lepidagathidis & & Guinea, Senagal, Guinea Bissau \\
\hline S. lutea & & Burkina Faso, Democratic Republic of Congo, Kenya, Mali, Nigeria, Sierra Leone \\
\hline S. macrantha & & $\begin{array}{l}\text { Angola, Central African Republic, Guinea, Cameroon, Liberia, Mali, Senegal, Chad, Sierra } \\
\text { Leone }\end{array}$ \\
\hline S. passargei & & Burkina Faso, Ghana, Guinea, Nigeria, Togo, Sudan, Tanzania, Zambia \\
\hline S. pinnatifida & & Ethiopia \\
\hline S. primuloides & & Ghana, Cote d'ivoire, Mali, Nigeria \\
\hline S. pubiflora & Sugarcane & Kenya, Mozambique, Tanzania \\
\hline S. yemenica & & Ethiopia \\
\hline
\end{tabular}

Source: Johnson et al., 1997; Khan et al., 2002; Mohamed et al., 2001; Timko et al., 2007 
Table 3. Reaction of rice cultivars to S. hermonthica, S.asiatica and S.aspera

\begin{tabular}{|c|c|c|c|}
\hline Reaction & Genotype & Striga spp. & Refs \\
\hline \multirow[t]{16}{*}{ Resistant } & ACC102196 & S. aspera & 5 \\
\hline & B3913F-16-5-ST-42 & S. hermonthica & 3 \\
\hline & Ble Chai & S. hermonthica & 3 \\
\hline & CG14 & $\ddagger S$. hermonthica, §S. aspera & $2,6,7$ \\
\hline & FARO 40 & S. hermonthica & 1 \\
\hline & FARO 48 & $\ddagger S$. hermonthica & 1 \\
\hline & IG10 & S. aspera & 5 \\
\hline & IR38547-B-B-7-2-2 & $\ddagger S$. hermonthica & 3,5 \\
\hline & IR47255-B-B-5-4 & S. hermonthica, S. aspera & 3,5 \\
\hline & IR47697-3-4-1 & S. hermonthica & 3,6 \\
\hline & IR49255-B-B-5-2 & S. hermonthica, S. aspera & 3,5 \\
\hline & Jean louis & S. asiatica & 4 \\
\hline & Nipponbare & S. hermonthica & 2,7 \\
\hline & WAB928-22 & S. hermonthica, S. aspera & 6 \\
\hline & WAB935-5 & S. hermonthica, S. aspera & 6 \\
\hline & WAB937-1 & S. hermonthica, S. aspera & 6 \\
\hline \multirow[t]{6}{*}{ Tolerant } & Azucena & S. hermonthica & 7 \\
\hline & FARO 11 & S. hermonthica & 1 \\
\hline & Kasalath & $\ddagger S$. hermonthica & 2,7 \\
\hline & M27 & $\ddagger S$. hermonthica, †S. aspera & 2,5 \\
\hline & Makassa & S. hermonthica, $\uparrow S$. aspera & 5 \\
\hline & $\mathrm{T} 2$ & S. hermonthica, S. aspera & 2,5 \\
\hline \multirow[t]{4}{*}{ Susceptible } & Bala & S. hermonthica & 7 \\
\hline & Dourado precoce & S. hermonthica & 3,4 \\
\hline & Namroo & S. hermonthica & 2,3 \\
\hline & IR64 & S. hermonthica & 7 \\
\hline
\end{tabular}

Refs: 1-Adagba et al., 2002, 2-Gurney et al., 2006, 3-Harahap et al., 1993, 4-Itoh et al., 2008, 5Johnson et al., 1997, 6-Johnson et al., 2000, 7-Kaewchumnong \& Price, 2008. Contradictory reaction reported with the same species: †Resistant, $\ddagger$ Susceptible, §Tolerant.

incidence also in Central, East and Southern Africa. The greatest damage occurs in the sahelian and savanna zones of Africa, which constitute the major rice growing areas where Striga problem is most severe. It has already been shown that FARO 48 is resistance to $S$. hermonthica while FARO 38, FARO 46 and FARO 45 are susceptible (Table 3). Studies conducted in western Kenya on rice tolerance to Striga showed that heavy infestation led to complete crop failure (Kuoko et al., 1992). Striga emergence in the local varieties ranged from 8-18 plants $\mathrm{m}^{-2}$. Gurney et al. (2006) reported a robust resistance in Nipponbare rice cultivar to $S$. hermonthica in postattachment experiment. In this cultivar the parasite failed to form xylem to xylem connection to the host plant root. Other studies have also shown Nipponbare having low numbers of Striga and emerging late thus concluding that the variety is resistant (Swarbrick et al. 2009). 
Striga tolerance and Quantitative trait loci in rice: Gurney et al. (2006) screened 31 rice cultivars of $O$. sativa, $O$. glaberrima and wild relatives of rice sourced from different ecologies in the world for Striga tolerance. All the cultivars were susceptible except for Nipponbare which exhibited high level of post-attachment resistance to Striga hermonthica. The result also showed detection of seven Striga resistance quantitative trait loci (QTL) (on chromosomes $1,4,5,6,7,8$ and 12) for postattachment in an advanced backcross inbred line (BIL) resource generated from Kasalath and Nipponbare. This result corroborated with the findings of Swabrick et al. (2009) who assessed QTL for resistance in rice (Koshihikali-Nipponbare BILs, Nipponbare-Kasalath cross and Kasalath-Koshihikari cross) to Striga hermonthica and concluded that chromosome 4 QTL in Nipponbare-Kasalath cross and Kasalath-Koshihikari cross overlapped between $6.5 \mathrm{Mbp}$ and $8 \mathrm{Mbp}$ on the physical rice genome. These findings narrowed down the position of Striga resistance which had been earlier reported by Gurney et al. (2006).

However, in the study conducted by Kaewchumnong and price (2008) on rice cultivars tolerance to Striga showed that the QTL for all rice traits in the Striga infected were present between position 139 and 169 cM on chromosome 1 . The QTL LOD scores ranged from 4.9 to 15.7 and they were significant at 3.2. There were two positions in the studies of Gurney et al. (2006) and Kaewchumnong and price (2008) that coincided. First is on chromosome 1 at position 46 cM between marker C1370 and R2417. The second is at position $32 \mathrm{cM}$ at marker R202 on chromosome 8. Kaewchumnong and price (2008) further showed that Chromosome 1 especially marker C1370 of rice seems to control both the establishment of Striga and the effect of Striga on rice plants. From these studies it can be deduced that there is an indication that genes for Striga tolerance exist in rice germplasm and further fine mapping may bring about examination of genes, and then narrow them down to find out their putative functions. This will enable understanding on the nature of tolerance and ultimately breeding for Striga-resistant rice plants.

\section{CONCLUSION}

Africa has complex systems of agricultural development ranging from bush clearing and cultivation to convectional agricultural production. Rice is slowly becoming food security crop in SSA. With the increasing population, pressure on cultivated land, changes in feeding habits and urbanization, rice consumption is likely to continue increasing. The area under production of upland rice (especially the new cultivars of NERICA) is under threat from Striga weed infestation. This therefore calls for suitable management Striga control strategies aimed at improving and filling in the gaps of the available mechanisms which have not been widely adopted by farmers. Priority should be geared towards understanding the parasite and the farmers farming systems so that any mechanism developed will be able to fit into the farmers' requirements. In addition breeding of cultivars that are resistant to Striga will be cost-effective to control the parasite as cultivation of resistant varieties does not require costly inputs from farmers. If at all resistant genes can be identified, they can be transferred to other cereals such as maize, millet and sorghum by marker-assisted selection through the use of synteny.

\section{REFERENCE}

Adagba, M.A., Lagoke, S.T. and Imolehin, E.D. (2002). Nitrogen effect on the incidence of Striga hermonthica (Del.) Benth in upland rice. Agron. Hungarica. 50: 145 150.

Ahmed, N.E., Sugimoto Y., Babiker, A.G., Mohamed, O.E., Ma, Y., Inanaga, S. and Nakajima, H. (2001). Effects of Fusarium solani isolates and metabolites on Striga germination. Weed Sci. 49: 354-358.

Berner, D.K., Winslow, M.D., Awad, A.E., Cardwell, K.F., Mohan Raj, D.R. and. Kim, S.K. (1997). Striga research methods - A manual, International Institute of Tropical Agriculture, Ibadan, Nigeria. 1-9.

Cochrane, V. and Press, M. (1997). Geographical distribution and aspects of the ecology of the hemiparasitic angiosperm Striga asiatica (L.) Kuntze: a herbarium study. J. of Trop. Ecol. 13: 371-380.

De Datta, S.K. (1981). Principles and practices of rice production. A Wiley Inter-sci. Publ. New York. 460512.

Doggett, H. (1952). Annual report of the Botanist Ukiriguru for year 1950. Annual report, Tanganyika Department of Agriculture, Dar es Salaam, Tanzania, 221-241.

Dugje, I.Y., Kamara, A.Y. and Omoigui, L.O. (2006). Infestation of crop fields by Striga species in the savanna zones of northeast Nigeria Agric. ecosystems and environ. 116: 251-254.

Ejeta, G. (2007). The Striga scourge in Africa: a growing pandemic. In: Ejeta G. and Gressel J. (eds). Integrating New Technologies for Striga Control: Towards ending the witch-hunt. World Scientific Publishing Co. Pte Ltd, 5 Tol Tuck Link, Singapore, 3-16.

Emechebe, A.M., Ellis-Jones, J., Schulz, S., Chikoye, D., Douthwaite, B., Kureh, I., Tarawali, G., Hussaini, M.A. and Kormawa, P. (2004). Farmers' perception of the striga problem and its control in Northern Nigeria. Exp. Agric. 40: 215-232. 
FAO. (2007). Rice Market Monitor. International Rice Commission Newsletter. Vol. 56, Rome, Italy.

Gethi, J.G., Smith, M.E., Mitchell, S.E. and Kresovich, S. (2005). Genetic diversity of Striga hermonthica and Striga asiatica population in Kenya. Weed Res. 45: 64-73.

Gurney, A.L., Slate, J., Press, M.C. and Scholes, J.D. (2006). A novel form of resistance in rice to the angiosperm parasite Striga hermonthica. New Phytol. 169: 199-208.

Harahap, Z., Ampong-Nyarko, K. and Olela, J.C. (1993). Striga hermonthica resistance in upland rice. Crop Prot. 12: 229223.

Hearne, S.J. (2009). Control - the Striga conundrum. Pest Manag. Sci. 65: 603-614.

Itoh, K., Tsukii, Y., Randriamahonina, V., Sago, R. and Yamaguchi, H. (2008). Rice cultivation and weed control in the Central highland and Mahajanga area in Madagascar. Kinki Weed Research Society proceedings at New Umeda Training Center, November 30, 2008. No. 18, Osaka, Japan.

Johnson D.E. 1996. Weed management in small holder rice production in the tropics. Natural Resources Institute. University of Greenwich Ghatham, Kent, UK. pp:11.

Johnson D.E., Riches C.R., Jones M.P. and Kent R. (2000). The potential for host resistance to Striga on rice in West Africa. In: Hausmann B.I.G., Hess D.E., Koyama M.L., Grivet L., Rattunde, H.F.W. and Geiger, H.H. (eds). Breeding for Striga Resistance in Cereals pp. 139-145. Proceedings of a Workshop, 18-20 August 1999, IITA, Ibadan, Nigeria. Markgraf verlag, Weikersheim, Germany.

Johnson, D.E., Riches, C.R., Diallo, R. and Jones, M.P. (1997). Striga on rice in West Africa; crop host range and the potential of host resistance. Crop Prot. 16: 153-157.

Jones, M.P. 1999. Food security and major technological challenges: The case of rice in Sub Saharan Africa. World food security Conference, Kyoto, Japan. 57-64.

Kaewchumnong, K. and Price, A.H. (2008). A study on the susceptibility of rice cultivars to Striga hermonthica and mapping of Striga tolerance quantitative trait loci in rice. New Phytol. 180: 206-216.

Khan, Z.R., Hassanali, A., Overholt, W., Khamis, T.W., Hooper, A. M., Pickett, J.A., Wadhams, L.J., and Woodcock, C.M. (2002). Control of witchweed Striga hermonthica by intercropping with desmodium spp. and the mechanism defined as allelopath. J. of Chem. Ecol. 28: 1871-1885.

Khan, Z.R., Midega, C.A.O., Hassanali, A., Pickett, J.A. and Wadhams, L.J. (2007). Assessment of different legumes for the control of Striga hermonthica in maize and sorghum. Crop Sci. 47: 730-736.

Kim, S., Adetimirin, V.O. and Akintunde, A.Y. (1997). Nitrogen effects on Striga hermonthica infestation, grain yield, and agronomic traits of tolerant and susceptible maize hybrids. Crop Sci. 37: 711-716.
Kouko, W.O., Okech, J.N. and Odhiambo, G.D. (1992). Rice varietal tolerancel resistance to Striga hermothica screening. KARI- Kibos, Annual report.

Kuiper, E., Groot, A., Noordover, E.C.M., Pieterse, A.H. and Verkleij, J.A.C. (1998). Tropical grasses vary in their resistance to Striga aspera, Striga hermonthica, and their hybrids. Can. J. Bot. 76: 2131-2144.

Mohamed, A.H., Ejeta, G., Butler, L.G. and Housley, T.L. (1998). Moisture content and dormancy in Striga asiatica seeds. Weed Res. 38: 257-265.

Mohamed, K.I., Musselman, L.J. and Riches, C.R. (2001). The genus Striga (scrophulariaceae) in Africa. Annals of Missouri Bot. garden, 88: 60-103.

Musselman, L.J. (1980). The biology of Striga, Orobanche, and other root-parasitic weeds. Annual review of phytopathol, 18: $463-489$.

Obilana, A.B. and Okumu, B.N. (2005). Interspecific hybridization between African and Asian rice species: Evaluation study report, UNDP SU/SSC and WARDA INT/00/922 Africa-Asia Joint Research.

Oswald, A. (2005). Striga control-technologies and their dissemination. Crop Prot. 24: 333-342.

Otsuka, K. and Kalirajan, K.P. (2006). Rice green revolution in Asia and its transferability to Africa: An introduction. The Developing Economies, 44: 107-222.

Parker, O. and Riches, C.R. (1993). Parasitic weeds of the world, biology and control. Long man press, London. 1-70.

Ramaiah, K.V. (1987). Breeding cereal grains for resistance to witchweed. In: Musselman L.J. (ed). Parasitic Weeds in Agriculture: Striga, Vol. 1: 227-242, CRC Press, Boca Raton, FL.

Rodenburg, J., Bastiaans, L. and Kropff, M.J. (2006). Characterization of host tolerance of Striga hermonthica. Euphytica, 147: 353-365.

Scholes, J.D. and Press, M.C. (2008). Striga infestation of cereal crops - an unsolved problem in resource limited agriculture. Current O. in Plant Biol. 11: 180-186.

Swarbrick, P.J., Scholes, J.D., Press, M.C. and Slate, J. (2009). A major QTL for resistance of rice to the parasitic plant Striga hermonthica is not dependent on genetic background. Pest Manag. Sci. 65: 528-532.

Timko, M.P., Gowda, B.S., Ouedraogo, J. and Ousmane, B. (2007). Molecular markers for analysis of resistance to striga gesnerioides in cowpea. In: Ejeta G. and Gressel J. (eds). Integrating new technologies for Striga control: Towards ending the witch-hunt. World Scientific Publishing Co. Pte Ltd, 5 Tol Tuck Link. Singapore, 1-14.

Watson, A.K., Ciotola, M. and Peden, D. (1998). Controlling of the noxious striga weed. International Development Research Centre, Ottawa, Canada. Weed Res. 35: 303309.

Woomer, P. (2004). New approaches to controlling Striga infestation: AATF Striga Management project. Farmers Journal, 1-3. 